\title{
Tangible Rewards or Intangible Rewards - Which Play Most Significant Role in Increasing Job-Hopping Behavior in Generation Y Employees in Pakistan?
}

\author{
Uresha (Corresponding author) \\ Karachi University Business School (KUBS), University of Karachi. \\ KU Circular Road, University of Karachi, Karachi, Pakistan. \\ E-mail: ureshasaif5@gmail.com \\ Dr. Danish Ahmed Siddiqui \\ Karachi University Business School (KUBS), University of Karachi. \\ KU Circular Road, University of Karachi, Karachi, Pakistan. \\ E-mail: daanish79@ hotmail.com
}

Received: Oct. 22, 2019 Accepted: Nov. 19, 2019 Online published: Nov. 21, 2019

doi:10.5296/ijhrs.v9i4.15685 URL: https://doi.org/10.5296/ijhrs.v9i4.15685

\begin{abstract}
Job hopping in the modern world is one of the major challenges that can be perceived in the current workforce market in Generation Y. The determination of this exploration is to scrutinize among tangible or intangible rewards, which plays most significant role in increasing job-hopping behavior in Generation Y employees in Pakistan. Tangible rewards were factored in 1. Market Competitive Pay, 2. Monetary Benefits and 3. Performance Incentives, whereas intangible rewards include 1. Quality of Work, 2. Work Life Balance, 3. Inspiration \& Values, 4. Organization Environment and 5. Future Growth \& Opportunity. The data was collected by means of close ended likert scale based questionnaire from 201 employees who belong to different industries in Pakistan. Confirmatory factor analysis \& Structured Equation Modelling were used for the examination. The study found that job hopping is optimistically associated with intangible rewards in Gen Y employees \& negatively associated with tangible rewards. This research provides insight to employers which factors must be considered while developing strategies for employees' compensation and retention in order to retain their competent employees and minimize job hopping
\end{abstract}


behavior in Generation Y employees.

Keywords: job hopping, generation Y / millennial, tangible rewards, intangible rewards, Pakistan, SEM

\section{Introduction}

\subsection{Background to the Study}

Job hopping refers to the pattern of changing organizations more frequently on owns willingness rather than in case of downsizing or company ceased to operate business. Job hopping has risen as an exceptionally significant work environment pattern. Fortune, Forbes, Fast Company, Entrepreneur, CNN Money, CNBC, New York Times, and the Los Angeles Times have all run articles on job hopping in previous three years, incorporating 7 articles in the Wall Street Journal since 2014. (Lake, Highhouse et al. 2018). With the dynamic worldview of Human Resource Management, employees' are deemed as an assets for today's organizations. It is essential to have a long haul viewpoint in overseeing and contemplation of employees as a potential resource, as opposed to just a variable expense. (Armstrong 2011). Organizations' prosperity is subject to their ability to fascinate, develop and preserve competent employees (Sims 2007). But, employees' turnover; particularly deliberate turnover has been progressively turning into a challenge for the organizations (Hom, Mitchell et al. 2012) to retain their talented employees. Having sufficient open doors in the professional world, employees change the organizations (Job Hopping) in light of different elements. Thus, it is important to see through the perspective of employers, the variables that impact job hopping, with the goal that this challenge can be investigated further.

An entrenched reward and gratitude framework are important to create wanted dimension of inspiration in the workers. Both rewards i.e. tangible \& intangible rewards help an organization to improve the inspirational dimension of the employees. Yet, a harmony among tangible and intangible rewards ought to be made by the employers according to requirements of the employees, as out dated, unlikely, less significant, confounded, and immaterial things will result in employees demotivation (Daniel and Metcalf 2005) which more or less subject to job hop. Tangible rewards like pay, monetary rewards \& advancements have its very own significance in employees' motivation. Undoubtedly money is the essential factor in employees' motivation, yet then again intangible rewards like gratefulness, a basic thanks you note, and delegation of authority, employee of the month / quarter / year and awards also play an energetic role in employees' motivation and enhance the organization performance. People possess individual qualities as per which they accept according to their very own esteem what is important to them (Armstrong and Taylor 2014). (Arthur 1994) contended that by following best practices of human resource, employers can change the employees' behavioral pattern to make reliability with the organizations. As factor of monetary rewards motivate the employee on one side, then the non-monetary rewards are additionally an asset of employees' motivation, and cost effective for the employers. An initiative of simply "Thank You" culture inside the organizations will acquire a decent change the conduct of employees towards making reliability with the organization (Daniel and Metcalf 2005). 
According to researcher's personal observation, this conduct of employees, moving from one organization then onto the next, is typical among employees' who are on average under 31-35 years of age. The presently employed individuals who are between the ages of 26-39 can be categorized as Generation 'Y'ers. In the past, different researches have been conducted in order to explore the reasons behind employee turnover and every time the result was different according to each generation. According to the background study on this research it is revealed that employees switch their jobs due to various reasons such as work life balance, labor mobility, voluntary turnover etc. However, it is assumed that a part of study is always absent or might differ according to the mindset of different people or geographical location. However, there is a scarcity of researches done on the job-hopping concept locally creating a curiosity to investigate job hopping within the Karachi, Pakistan context.

\subsection{Problem Statement}

Job hopping would make the employers come across the hazards of information spillover for some businesses \& increase the expenses of trainings and developing new hires to replace the skillful employees. Organizations belongs to technology sectors in Singapore are more anxious about the job hopping as they are concerned that their trade secrets would be leaked $\&$ the acquired technology would be moved to competing organizations (Chng, Low et al. 1986). Organizations in diverse states like Germany, Japan \& America criticized that those employees can't be trained and developed who would be expected to switch jobs as they were poached by their competitors after they've already invested heavily in trainings and developing (Lim and Chew 1998).

Job hopping for salary increase has become the norm. Employees switch jobs repeatedly would create labor scarcity in the organizations (Aswathappa 2005) and would not only badly effect the efficiency of organizations but also the economy (Yah 2013). For that reason, managers have to prepare how to accord with the complications of expanded labor cost along with reduced productivities (Bullard 2003). Such as, Japanese organizations is more concerned about job hopping as Japanese managers believed that all of their time, money and efforts put in training and developing employees were fruitless when Thai workforce resigned after learning the different skills (Reader and Soederberg 2013). When the expert and skilled employees resign, employers have to expend money on replacement/substitution, for example advertising, interviewing, training \& developing new hires (Nkomo and Thwala 2009) (Cloutier, Felusiak et al. 2015).

The rising problem of job hopping is not only being observed in entry level employees, but the managerial level employees also. Some job hoppers who are at management level did not have any real commitments to increase organizations' productivity and profitability (Witt 2016). The reason of changing employments along these lines is to cover the terrible aftereffects of their futile management strategies like the efficiency and employees' commitment are far more vicious subsequent to applying the technique they proposed.

"A high ratio of job-hopping behavior has been observed among the employees working in different industries which causes chaos and abruption in the work efficiency of any organization. This behavior won't only affect the organizations' reputation but have an impact 
over an employee`s profile also in the long run.

Different researches on different generations have demonstrated that in spite of better than expected compensations, there is high turnover in certain companies. This emphases to the fact that solitary financial or tangible rewards don't contribute in persuading employees (Aguinis and Glavas 2012) to continue in the same organization. As a result, it was advocated that salary increase or compensation isn't sufficient to acquire well \& increased worker's performance (Jones and George 2014).

Therefore, researcher decided to study which play most significant role in increasing job-hopping behavior in Generation Y employees in Pakistan? - Tangible rewards or Intangible rewards. This research not only helps to identify the role of tangible \& intangible rewards in job hopping behavior but also differentiates between these two.

\subsection{Gap Analysis}

In the literature, different researches have been conducted on the job-hopping behavior \& voluntarily turnover employees intention belongs to different generations worldwide and almost every research which was conducted on generations have discovered that generally, Generation Y are less faithful to their employed organizations (D'Amato and Herzfeldt 2008). It is evidenced from a study of (Naresh and Rathnam 2015) that employees moving frequently or switching job from one to another job or switch between organizations in order to get a speedy monetary increase or having career development.(Daming, Xiaoyun et al. 2010) researched to study on the young migrant employees' attitudes regarding job hopping as well as their occurrence \& causes of moving from jobs to jobs frequently. Results demonstrated that the more youthful the employee, the more frequently they switch employments. (Lau and Pang 1995) carried out a qualitative research to know undergraduate students' future perceptions. Two students revealed it was an admissible norm to change job quickly or within initial 6 month and normally companies have already predict this to be happen. Researchers concluded that the main factors were organization's environment and whether employee is cultural fit or not it seemed like that undergraduate employees make "job" decisions rather than "career" decisions.

(Kafeel and Alvi 2015) investigated what play important role in growing turnover intention: job hopping or perceived organizational politics? 125 employees randomly selected from Lahore Pakistan's banking industry are chosen. Results demonstrated that perceived organizational politics is an ultimate root cause of workforce turnover intention as compared to job hopping. (Cennamo and Gardner 2008) discovered Generation Y appreciating work life balance, ways of life, profession advancement more than different generation. As indicated by (Cennamo and Gardner 2008), the valuations of Generation Y are more autonomy related. It's important the literature review on the purposes behind job hopping, "money" or "the compensation" wasn't given prominence as anticipated. Supporting that, (Weyland 2011) states that Generation $\mathrm{Y}$ fundamental concern is to do significant work in an area that provides them provocation, sense of accountability, fun \& adaptability, yet not to get compensation \& status. 
After reviewing different researches, researcher observed that no one researched on rewards along with Job Hopping behavior in Generation Y so that there was a room to study about those factors which play most significant role in increasing Job-Hopping Behavior in Generation Y employees especially in Pakistan. This research directly investigate that which play most significant role in increasing Job-Hopping Behavior in Generation Y employees? Tangible Rewards or Intangible Rewards. As tangible rewards include many types of benefits i.e. Market competitive pay, performance incentives and other monetary benefits as well, so it becomes difficult to analyze the role of intangible rewards in increasing job-hopping behavior. A distinct approach has not been adopted by the researchers to measure the role of intangible rewards separately.

\subsection{Objectives of the Study}

In this study, researcher aim is to comprehend the perception \& conception of job hopping from the employees' viewpoint in Karachi, Pakistan. The main reason of collecting more data from employees instead of HR personnel is that, the HR personnel can only share about whether job hopping phenomenon is existed in their organizations or its apparent reasons of their speedy turnover. Hence, researcher analyzed how employees in Karachi, Pakistan characterize job hopping regarding "the short timeframe" and "frequency" just as how they consider job hopping.

The primary aim of current research is to explore among tangible or intangible rewards, which plays most significant role in increasing job-hopping behavior in Gen Y employees in Pakistan. The question to be examined in this research that whether tangible or intangible rewards has an impact on the Job Hopping behavior of Gen Y or not. This study is related to human resource management. This study is helpful to understand how job hopping can be minimized so that employees' as well as employers' goals and objectives can be achieved. This research takes into account only the effect of tangible \& intangible reward on job hopping behavior of Gen $\mathrm{Y}$ and no other aspects are considered that have positive or negative influence on Job Hopping. Tangible rewards were factored in 1. Market Competitive Pay, 2. Monetary Benefits and 3. Performance Incentives, whereas Intangible rewards include 1. Quality of Work, 2. Work Life Balance, 3. Inspiration \& Values, 4. Organization Environment and 5. Future Growth \& Opportunity. Through this research, a struggle has been made to analyze the role of Tangible and Intangible rewards in increasing job-hopping behavior in Generation Y employees in Karachi, Pakistan. Considering this, employees who are under the age of 40 years by the year 2019 will be deemed as Generation Y for this study.

\subsection{Significance of Study}

It has been described in above discussion that how researchers characterizing job hopping, why employers or HR personnel are much distress about job hopping, who potential job hoppers would be \& why people hop from one jobs to another. Many researches, books and articles are discussing about job hopping phenomenon in the US, Asia or different nations. Although considering the full picture behind job hopping behavior is vital, it's also imperative to understand the opinions or attitudes individuals hold about job-hopping when choosing to involve in job hopping behaviors or not. Do they think it is not problematic for 
them to change jobs as often as possible and for what reason do they suspect as much?

There are 3 imperative means in which this research will add to the present literature of tangible \& intangible rewards \& job hopping behavior in Gen Y. Firstly, this research examines different industries employees' of Karachi, Pakistan \& gives an insight why employees prefer not to stay in same organization for longer period? This research will reveal an insight into the tangible and intangible employees' reward needs who are employed in different organization of Karachi, Pakistan. This research will also act as guidance to employers in identifying factors that causes employees' to leave their jobs and how to minimize voluntarily employee turnover. This research data will also help the upcoming researchers to conduct the identical studies on the Generation $\mathrm{Z}$ and will help the employers to formulate strategic employee compensation plus retention plan in order to keep the competent employees for the longer - run.

\section{Literature Review}

\subsection{Definition of Job Hopping}

Job Hopping is a phenomenon that makes human resources experts face troubles in acquiring workforce \& how to retain employees in their organizations. Human resource professionals from various nations in professional forums had a similar view that job hopping had just turned into a culture \& this turnover culture was likewise famous in Pakistan (YUEN 2016). In the literature, job hopping defines as switching jobs frequently (Cumming 2012). Job hoppers are typically seen as the individuals who can't remain in an organization for a longer time period (Mtungwa 2009), or on the other side the individuals who are investing limited or short time \& energy and having less enthusiasm for their employments (Bills 1990).

\subsection{Nature of Job Hopping}

As it was cited by (Khatri, Budhwar et al. 1999) a few researches have explained that higher the age, job tenure $\&$ the pay bracket of the employees, bring down the turnover; i.e. intention to switch job. (Dougherty, Dreher et al. 1993) examined that the MBAs which were considered as Careerist were less interested to switch jobs more frequently than the bachelor's business graduate. Because the author found that MBAs possessed some certain qualities of maturity than early career birds. The idea of job hopping additionally contrast dependent on the industry or business that the employees work for. For instance, when an employee experiences industry explicit abilities or profession explicit aptitudes, such employee would switch among a few companies in a similar industry, yet not in various professions (Korpi and Mertens 2003). (Hamori 2010) finds that 30\% of switches starting with one organization then onto the next are downgrading and $24 \%$ of moves are from a known name to a well-known name including bow out in title. She additionally expresses that $17 \%$ had experienced in at least 3 or more sectors.

\subsection{Reasons for Job Hopping}

Job hopping attitude is ascribed to employees valuing more on tangible rewards. Materialistic values is one reason for millennial job hopping attitude (Campbell and Campbell 1997). 
Individuals hopping from their positions as often as possible because of their personal responsibility and self-interest crosswise over various nations. Individuals at the higher level regarded that pay rates and different benefits are the ultimate motivator for job hopping (Netswera and Rankhumise 2005). (Taylor and Zimmerer 1992) explain, overtask, job uncertainty, confusion, downsizing are some reasons behind voluntarily turnover \& they can be measured as organizational factors. Various other organizational aspects that can cause serious job hopping are insufficient training, less career growth opportunities and challenging and interesting task provided by the employer, leadership issues (Hartman and Yrle 1996) irrational handling for a colleague, being ignored for career advancement, or being approached to achieve something against one's conviction (Mitchell, Holtom et al. 2001).

Some research experts suggested that switching job is simply the methodology that workers use to preserve themselves having intensity \& qualities in the labor market \& to build up their abilities through employed in various organizations (Lankard 1995). Work environmental factors likewise contributes to job hopping. Job hopping is because of the movements in labor market or diverse workplace. For instance, one reason for Librarians to continue switching employments is that there are just contractual and temporary positions are accessible in the job market (Gordon 2006).

(Silverman 2004) contended that organizations having an equilibrium between tangible \& intangible reward will show better execution. This will impart a positive effect in the brain of employees that they are esteemed, trusted and regarded. Compensation is the most significant piece of the reward framework, yet intangible rewards are seen progressively significant by the employees on every day work and it is required that monetary and non-monetary rewards ought to go parallel. Better working conditions, different rewards and applaud projects spur employees to perform well. Offering different rewards and applaud projects to the employees make them beyond any doubt that they are being esteemed by the association. These sentiments will help employees' inspiration and, in this manner, expands efficiency of organization (Freedman 1978).

A definitive reason for remunerations and acknowledgment is to keep the employees motivated \& committed. In the present vigorous environment intangible rewards are likewise the employees need, as just monetary remuneration can't build the persuasive dimension to keep employees committed \& satisfied (La Motta 1995). The organization strength relies on the connection between the employees and their line managers. Managers have impact on inspiration \& employees satisfaction (Morris 1981). (Ellis and Pennington 2004) expressed that intangible rewards motivate employees in longer term.

Intangible rewards increment the work life balance of employee (Saif, Nawaz et al. 2012). The researchers ought to deem the results that the rewards may cause for both employee \& employer. To think about intangible rewards, they exist in the work itself like work gratification, successfully carrying out a challenging task, recognition from the top management, \& independence; though tangible rewards are substantial in nature like salary, fringe benefits, bonuses, \& promotions (Ajila and Abiola 2004). According to (bin Abdul Aziz) intangible rewards for the most part influence the performance of employees. The 
effect of non-monetary rewards to satisfy the employees is not excessively. Rewards which are utmost important for the employees are career advancements, monetary recompenses, leaves, medical benefits and contribution in basic leadership process. However, it ought to be noticed that 'salary' wasn't stressed in past researches as an explanation behind job hopping. Supporting that, (James 1991)expressed that "Money is not the fundamental reason" for work turnover.

\subsection{Perception towards Job Hopper}

People have various observations to the individuals who hop from organizations to organizations as often as possible in a short timeframe. Job hoppers are portrayed as switching employments like changing cloths as faithfulness to employers is not that significant as previously (Aswathappa 2005). There are additionally adverse observations to job hoppers from employers. They were seen as always prepared to quit the organization, mercurial, less committed and irresponsible (Nkomo and Thwala 2009).

\subsection{Consequences of Job Hopping to Organization}

Job Hopping would make the organizations experience the dangers of information overflow for certain enterprises $\&$ rise the expenses to train new hires to replace the talented specialists. Companies belong to technological industry in Singapore are worried much about job hopping as they are concerned about that the competitive advantages would be let out $\&$ the attained technology would be exchanged to challenger organizations (YUEN 2016). Organizations in various nations like Germany, Japan \& America criticized that they can't prepare those employees who might probably switch jobs as their rivals would poach their trained \& skilled employees after they've as of now invested such a handsome amount in training (Lim and Chew 1998).

When the talented and competent employees left, employers expect to invest money on substitution, for example advertising \& interviewing, train \& develop new employee (Nkomo and Thwala 2009). Though, even organizations are eager to train the new hires, they are stressed about facing the same issue again. The issues of job hopping are found in talented specialists, yet additionally the managers. Some job hoppers who are in top management positions didn't have any genuine commitments to improve employers' efficiency (Witt 2016).

\subsection{Defining Generation Y/Millennial}

Individuals from a similar generation are believed to have comparable qualities, convictions, behavior or attitude. A generation is characterized as "a gathering of individuals or companions who share birth years and experiences as they travel through time together, affecting furthermore, being affected by an mixture of basic variables" (Kupperschmidt 2000).

According to (Helyer and Lee 2012) Gen Y which is also known as millennial is reflected as individuals who were conceived in the middle of the year 1979-1991. According to definition states above, Generation Y must be 28-40 years of age as per year 2019. (Weyland 2011) 


\section{Macrothink}

International Journal of Human Resource Studies

ISSN 2162-3058 2019, Vol. 9, No. 4

defined Gen Y are those who were born between 1980-1990. In the study of (Friedell, Puskala et al. 2011) he stated Gen Y refers to those people who born between 1980 \& 2003. While in (Lambert 2015)'s study Gen Y considered as individuals born between 1976 and 2000 .

Regardless of how different research specialist describe the similar generation, job hopping behaviors look like to be more common in Gen $\mathrm{Y}$ if compared with other generations (Twenge 2010). Millennial would like to stay for longer period in an organization if that organization offers them advance technologies to do their work \& give them exciting, challenging \& engaging work responsibilities (Angeline 2011).

\subsection{Theoretical Framework}

This research examined 2 independent variable \& 1 dependent variable. The independent variables include Tangible Rewards and Intangible Rewards. While the Job Hopping is the dependent variable. Here we break Tangible and Intangible Rewards into \# of sub-particles i.e.; Market Competitive Pay, Monetary Benefits and Performance Incentives \& Quality of Work, Work Life Balance, Inspiration and Values, Organization Environment, Future Growth \& Opportunity respectively.

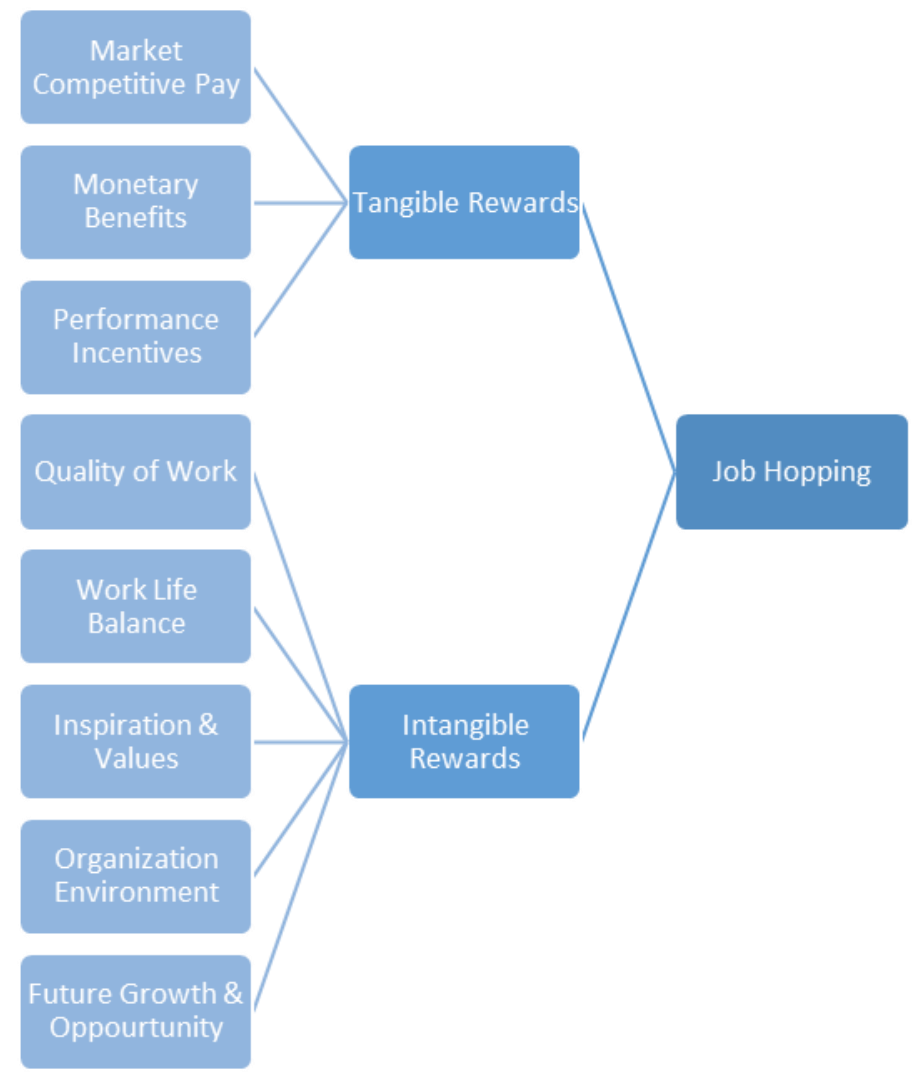

Figure 1. Theoretical Framework 


\subsubsection{Tangible Rewards}

\subsubsection{Market Competitive Pay}

In this study, researcher focus on workers' perceptions of fair market competitive pay, as this aspect captures persons' assessment of their exchange with the organization. (Adams and 2-W 1963) equity theory has been to a great extent received to explain these trades, explicitly in connection to rewarding \& recognition policies (Arnold, Landry et al. 2009). However, few researches have empirically inspected this relationship. When employees are asked why they work, money is one of the most generally mentioned reasons (Jurgensen 1978). (Dries, Pepermans et al. 2008) stated that market competitive pay / salary is as yet a significant work esteem that decides career success for all generations.

\subsubsection{Market Competitive Pay}

Content theory embraces the effort of David McClelland, Abraham Maslow and other psychologists. Content theory are exceptionally related with monetary rewards, things that are concrete like bonuses and will help develop employees' physiological conditions. Job Hopping practices are ascribed to employees esteeming much on monetary benefits. Materialistic qualities is one purpose behind Generation Y job hopping behavior (Campbell and Campbell 1997, Ben-Ari and Clammer 2013). (YUEN 2016) stated when different organizations offered better monetary benefits such as bonus, commissions, profit sharing and stock options etc. employees would then hop from the current employer to another.

\subsubsection{Performance Incentives}

A remuneration package comprises of money related rewards, for example, compensation and benefits. Generation Y employees will prefer to remain in organization that gives a handsome salary with other benefits (Phillips and Roper 2009). Earlier researchers have revealed an optimistic correlation between pay for performance \& retention of millennial (Kim, Knight et al. 2009, Brown, Thomas et al. 2015). Pay for performance remunerate workers with higher pay for accomplishing higher performance objectives (Kilber, Barclay et al. 2014). Conferring to Vroom's Expectancy Theory worker's performance depends on individual variables, for example employees may have different objectives yet they can be persuaded if: There is an optimistic correlation between performance \& efforts. Desirable reward will be resulted in higher performance. (Vroom and Motivation 1964).

\subsubsection{Intangible Rewards}

\subsubsection{Quality of Work}

Employees channel their extra ordinary efforts into their work if they start believing that it has meaning and is beneficial and acknowledged. It tends to be a motivator to join a specific organization or profession (Armstrong and Murlis 2007). (Robertson, Smith et al. 2001) developed 5 standards for the advancement of compensating employees' jobs and role. They identified 5 sorts of influence around there:

Influence skill variety - furnishing chances to employees to perform a several responsibilities 
and to club responsibilities;

Influence task identity - consolidating responsibilities to shape systematic work entities.

Influence task significance - forming natural work groups and educating employees regarding the significance of their work.

Influence autonomy - providing employees' obligation regarding deciding their own working frameworks and settling on their own choices;

Influence feedback - opening and utilizing feedback channels.

\subsubsection{Work Life Balance}

Reward theory of work life balance portrays the efforts intended at countering unconstructive encounters in a single area through increased efforts for idealistic encounters in another area. (G. Vijaya Kumar 2017). An example would be a dissatisfied employee focused more on household than work, or a satisfied employee concentrated on work all the more yet settles on domestic life therefore reallocating his preferences for being glad in one recognize dilemmas in the other (Edwards and Rothbard 2000).

In view of the past examinations discoveries, both Gen X \& Millennial esteemed work-life balance \& autonomy (Yeaton 2008) furthermore, have the propensity of job hopping (Armour 2005).

\subsubsection{Inspiration and Values}

Theory Y presented by Douglas McGregor in 1960 states that Theory Y managers give employees' numerous opportunities for learning and promotion. It is rightly said employee's first boss is the reason for his/her career growth. Individuals join organizations and leave bosses. Employees have "that's it" instant when they choose to remain or go either because of their manager work or completes its exercises in a manner they care about or because of the fact that the contention with their own qualities turns out to be too awkward to even consider tolerating (Armstrong and Murlis 2007). As (Goleman, Boyatzis et al. 2001) states that "a cranky and heartless manager makes a toxic association loaded up with negative under achievers who disregard opportunities; a rousing, comprehensive pioneer brings forth acolytes for whom any challenge is manageable."

\subsubsection{Organization Environment}

Organization environment also contributes to the job hopping phenomena. Employees are gradually settling on employment decisions dependent on organizations' standing and steady workplaces. Millennial prefer to remain with organizations that furnish a better working environment (Naim and Lenka 2018). A better environment consist of the physical and social environment (Williams and Turnbull 2015). A better physical environment consist of the open space, lighting, interior design and ambience of the office (Bencsik, Horváth-Csikós et al. 2016) where as a better social environment comprises the workload of the employee and management attitude (Zeiss 2010). Conferring to Herzberg's theory of motivation's hygiene factors; these factors will not urge employees to work hardest yet they will cause them 


\section{Macrothink}

International Journal of Human Resource Studies

ISSN 2162-3058

2019, Vol. 9, No. 4

become unmotivated if they are absent. Theory's one of the hygiene factor is working condition / environment which means utensils and the working environment should be harmless, hygienic and fit for purpose.

\subsubsection{Future Growth and Opportunity}

In a worldwide economy, organizations are progressively constrained to broaden the knowledge \& skills of their employees. In this manner, employees are more concern for improving their abilities, as they perceive the need to continually grow their capabilities so as to support their employability. Accordingly, growth opportunities \& development are among the most reliable indicators of optimistic, singular level results, for example, attitude inspiration, \& strengthening (Aguinis and Kraiger 2009). Millennial incline toward occupations that offer not only professional but personal growth also. Therefore, they are very much concerned about growth opportunities and development prospects inside the organization (Martin, Tulgan et al. 2001). According To Alderfer's ERG (Existence, Relatedness and Growth) Theory presented by Clayton Alderfer, he said that when needs in a lower classification i.e. existence and relatedness need are met then employees try harder to meet a higher class need i.e. growth need. In this manner, organizations that are unsuccessful to offer growth opportunities to millennial are probably going to face a high job hopping behavior (Macky, Gardner et al. 2008).

\subsection{Hypothesis}

HO: Job hopping in Generation ' $\mathrm{Y}$ ' Employees is negatively associated with Tangible Rewards.

H1: Job hopping in Generation ' $\mathrm{Y}$ ' Employees is positively associated with Tangible Rewards.

HO: Job hopping in Generation ' $\mathrm{Y}$ ' Employees is negatively associated with Intangible Rewards.

$\mathrm{H} 2$ : Job hopping in Generation ' $\mathrm{Y}$ ' Employees is positively associated with Intangible Rewards.

\section{Research Methodology}

\subsection{Nature of Study}

This research is exploratory in nature $\&$ its objective to investigate which play most significant role in increasing Job-Hopping Behavior in Generation Y employees? - Tangible Rewards or Intangible Rewards. The researchers also expect to find out the employees and HR personnel's perceptions regarding job hopping behavior.

\subsection{Population and Sample}

Primary \& secondary data were used for conducting this research because, primary data is fruitful to find job hopping behavior of Generation Y employees in Karachi while secondary data is fruitful for analyzing prior researches. Researcher used non-probability sampling. 


\section{Mll Macrothink}

International Journal of Human Resource Studies

ISSN 2162-3058

2019, Vol. 9, No. 4

Researcher used both sampling, the convenience sampling and self-selection sampling, because of time constraints but to maintain research quality level, the sample size is 200 . The objective population for this research paper is those workers who are working somewhere in any public and private organization in Karachi, Pakistan. In our sample of complete 200 members, male \& female respondents filled the polls. Age of the respondents were between 20-46 years \& their qualifications were fluctuating between Bachelors to M.Phil./PhD level.

\subsection{Instrument}

The instrument used for collecting responses was a questionnaire that was floated online filled by respondents who belong to different industries of Karachi, Pakistan.

\subsection{Instrument Development}

Surveys appropriated was in English on the grounds that practically $80 \%$ of the sample belongs to knowledge workers which will be easy to maintain the balance between living standard and education level etc. Following are the instruments in detail. The inquiries of job hopping, inspiration \& values and organization environment were received from (YUEN 2016) It had 13, 4 and 2 items respectively. The inquiries of market competitive pay, monetary benefits, performance incentives and future growth \& opportunity were embraced from (Al-Nsour 2012) with 2-3 items each. Quality of work and work life balance inquiries were adopted from (Hirschfeld 2000) and (Smith 2010) respectively with 3 items each. All questions were designed in Likert Scale $(1=20 \%$ Agreement $2=40 \%$ Agreement, $3=60 \%$ Agreement, $4=80 \%$ Agreement, $5=100 \%$ Agreement.

\subsection{Content Validity}

The content validity was ensured by the researcher for this research in light of the fact that the moral thought of any individual has not been impacted during the research. In addition, the sample questionnaire was firstly circulated among the specialists or experiences individuals to analyze topic relevancy. The variable chosen by the researcher were unquestionably identified with the research topic \& deviation from subject was highly avoided.

\subsection{Tools and Techniques}

The statistical measurable strategies to investigate the information were partial least square (PLS) \& reliability statistics applying the Statistical Package for Social Sciences SPSS software \& Smart PLS.

\section{Empirical Analysis}

\subsection{Descriptive Statistics}

Table 1. Frequency Distribution

\begin{tabular}{|c|c|c|c|}
\hline Variable & Category & Frequency & \%age \\
\hline City & Karachi, Pakistan & 201 & 100 \\
\hline & $1970-1974$ & 1 & 0.50 \\
\hline
\end{tabular}




\begin{tabular}{|c|c|c|c|}
\hline \multirow{5}{*}{ YOB } & $1975-1979$ & 3 & 1.49 \\
\hline & $1980-1984$ & 8 & 3.98 \\
\hline & $1985-1989$ & 27 & 13.43 \\
\hline & $1990-1994$ & 106 & 52.74 \\
\hline & $1995-1999$ & 56 & 27.86 \\
\hline \multirow{6}{*}{ Ages (In Years) } & $20-25$ & 95 & 47.26 \\
\hline & $26-30$ & 82 & 40.80 \\
\hline & $31-35$ & 16 & 7.96 \\
\hline & $36-40$ & 5 & 2.49 \\
\hline & $41-45$ & 2 & 1.00 \\
\hline & 46 Plus & 1 & 0.50 \\
\hline \multirow[b]{2}{*}{ Gender } & Male & 127 & 63.18 \\
\hline & Female & 74 & 36.82 \\
\hline \multirow[b]{2}{*}{ Marital Status } & Single & 155 & 77.11 \\
\hline & Married & 46 & 22.89 \\
\hline \multirow{3}{*}{ Education } & M.Phil. / PhD & 9 & 4.48 \\
\hline & Masters & 111 & 55.22 \\
\hline & Bachelors & 81 & 40.30 \\
\hline \multirow{5}{*}{ Income } & $11,000-20,000$ & 42 & 20.90 \\
\hline & $21,000-30,000$ & 38 & 18.91 \\
\hline & $31,000-40,000$ & 46 & 22.89 \\
\hline & $41,000-50,000$ & 31 & 15.42 \\
\hline & 51,000 Plus & 44 & 21.89 \\
\hline \multirow{5}{*}{ Job Level } & Fresh / Entry Level & 68 & 33.83 \\
\hline & Officer / Sr. Officer / Jr. Manager Level & 87 & 43.28 \\
\hline & Assistant / Associate / Deputy Manager Level & 19 & 9.45 \\
\hline & Manager / Sr. Manager / General Manager & 17 & 8.46 \\
\hline & $\mathrm{CEO} / \mathrm{CFO} / \mathrm{CKO}$ & 10 & 4.98 \\
\hline
\end{tabular}

Table 1. Frequency distribution depicted that all the respondents belongs to city Karachi, Pakistan. Majority of the respondents belongs to male gender (63.18\%), born between $1990-$ 1994 (52.74\%), having age between 20 - 25 (47.26\%), holds Master's degree (55.22\%), belong to single marital status $(77.11 \%)$, earning income up to 31,000-40,000 (22.89\%) and working on Officer / Sr. Officer / Jr. Manager Level (43.28).

Table 2. Descriptive Statistic

\begin{tabular}{|c|l|r|r|r|}
\hline Variables & \multicolumn{1}{|c|}{ Descriptive Statistics } & Mean & Std. Error & Std. Deviation \\
\hline Job Hopping & $\begin{array}{l}\text { Did you have any experiences of } \\
\text { quitting a job within 1 year? }\end{array}$ & 2.05 & 0.069 & 0.984 \\
\cline { 2 - 5 } & $\begin{array}{l}\text { 2. How many times have you switched } \\
\text { jobs (including changing occupation } \\
\text { types and organizations as well as Job } \\
\text { Hopping experiences)? }\end{array}$ & 2.78 & 0.128 & 1.82 \\
\hline
\end{tabular}




\begin{tabular}{|c|c|c|c|c|}
\hline & $\begin{array}{l}\text { Within how much time do you think a } \\
\text { person change jobs can be defined as } \\
\text { changing jobs frequently? }\end{array}$ & 1.59 & 0.052 & 0.743 \\
\hline & $\begin{array}{l}\text { To what extent do employers, human } \\
\text { resources managers or supervisors } \\
\text { agree with your Job-Hopping behavior? }\end{array}$ & 2.78 & 0.083 & 1.176 \\
\hline & $\begin{array}{l}\text { To what extent do parents, siblings or } \\
\text { spouses agree with your Job-Hopping } \\
\text { behavior? }\end{array}$ & 3.01 & 0.09 & 1.279 \\
\hline & $\begin{array}{l}\text { To what extent do friends and } \\
\text { colleagues agree } \\
\text { Job-Hopping behavior? }\end{array}$ & 3.1 & 0.08 & 1.14 \\
\hline & $\begin{array}{l}\text { Job Hopping records on your resume / } \\
\mathrm{CV} \text { affects the opportunities of getting } \\
\text { job interview. }\end{array}$ & 3.44 & 0.091 & 1.287 \\
\hline & $\begin{array}{l}\text { Job Hopping records on your resume / } \\
\mathrm{CV} \text { affects bargaining power (e.g. } \\
\text { fighting for better remuneration in your } \\
\text { next job). }\end{array}$ & 3.51 & 0.083 & 1.171 \\
\hline & $\begin{array}{l}\text { I am satisfied with my current resume / } \\
\text { CV? }\end{array}$ & 3.51 & 0.084 & 1.192 \\
\hline & $\begin{array}{l}\text { I am looking for another more ideal job } \\
\text { than the one I now work in. }\end{array}$ & 3.4 & 0.098 & 1.383 \\
\hline & $\begin{array}{l}\text { I have thought seriously about changing } \\
\text { organizations since I worked in the } \\
\text { current company for no more than } 1 \\
\text { year. }\end{array}$ & 2.98 & 0.096 & 1.358 \\
\hline & $\begin{array}{l}\text { When I think that I am not satisfied by } \\
\text { my company (e.g., no opportunities for } \\
\text { learning new knowledge or skills, } \\
\text { promotion or rising pay), I will be going } \\
\text { to hop job. }\end{array}$ & 3.7 & 0.091 & 1.289 \\
\hline & $\begin{array}{l}\text { I think I would not like to be working } \\
\text { for this organization for more than } 1 \text { to } \\
2 \text { years from now. }\end{array}$ & 3.11 & 0.102 & 1.442 \\
\hline $\begin{array}{l}\text { Market } \\
\text { Competitive } \\
\text { Pay }\end{array}$ & $\begin{array}{l}\text { My Organization provides enough } \\
\text { payment/Salary to meet the } \\
\text { requirements of life. }\end{array}$ & 2.85 & 0.088 & 1.253 \\
\hline & $\begin{array}{l}\text { My Organization provides market } \\
\text { competitive pay to employees. }\end{array}$ & 2.92 & 0.086 & 1.224 \\
\hline & I feel satisfied with my pay structure. & 2.82 & 0.093 & 1.316 \\
\hline $\begin{array}{l}\text { Monetary } \\
\text { Benefits }\end{array}$ & $\begin{array}{l}\text { The organization provides overtime } \\
\text { payment to employees after working }\end{array}$ & 2.69 & 0.101 & 1.437 \\
\hline
\end{tabular}




\begin{tabular}{|c|c|c|c|c|}
\hline & hours. & & & \\
\hline & $\begin{array}{l}\text { The organization provides different } \\
\text { allowances for employees (i.e. medical, } \\
\text { transport, maintenance, mobile etc.). }\end{array}$ & 3.2 & 0.094 & 1.33 \\
\hline & $\begin{array}{l}\text { The organization provides a fair and } \\
\text { adequate compensation on retirement. }\end{array}$ & 2.95 & 0.094 & 1.335 \\
\hline $\begin{array}{l}\text { Performance } \\
\text { Incentives }\end{array}$ & $\begin{array}{l}\text { The organization provides rewards for } \\
\text { employees according to their } \\
\text { performance. }\end{array}$ & 2.88 & 0.092 & 1.302 \\
\hline & $\begin{array}{l}\text { The organization provides bonuses for } \\
\text { employees according to their post and } \\
\text { consistent with their level of } \\
\text { performance. }\end{array}$ & 2.95 & 0.097 & 1.37 \\
\hline & $\begin{array}{l}\text { The organization provides financial } \\
\text { incentives to employees when they } \\
\text { work professionally. }\end{array}$ & 2.85 & 0.092 & 1.311 \\
\hline $\begin{array}{l}\text { Quality of } \\
\text { Work }\end{array}$ & $\begin{array}{l}\text { My job gives me the chance to do } \\
\text { something that make use of my } \\
\text { abilities. }\end{array}$ & 3.42 & 0.095 & 1.34 \\
\hline & $\begin{array}{l}\text { I am satisfied to the amount of work I } \\
\text { do. }\end{array}$ & 3.31 & 0.089 & 1.263 \\
\hline & $\begin{array}{l}\text { My job gives me the chance to try my } \\
\text { own methods of doing the job. }\end{array}$ & 3.17 & 0.099 & 1.398 \\
\hline & $\begin{array}{l}\text { I have freedom to use my own } \\
\text { judgment. }\end{array}$ & 3.13 & 0.095 & 1.347 \\
\hline & $\begin{array}{l}\text { My job gives me the feeling of } \\
\text { accomplishment. }\end{array}$ & 3.29 & 0.093 & 1.315 \\
\hline $\begin{array}{l}\text { Work Life } \\
\text { Balance }\end{array}$ & $\begin{array}{l}\text { Work-life balance does not affect a } \\
\text { person's quality of work }\end{array}$ & 2.62 & 0.091 & 1.291 \\
\hline & $\begin{array}{l}\text { Work-life balance leads to better job } \\
\text { performance. }\end{array}$ & 3.53 & 0.093 & 1.319 \\
\hline & $\begin{array}{l}\text { The availability of flexible work } \\
\text { arrangements will affect my decision } \\
\text { when choosing an employer. }\end{array}$ & 3.56 & 0.085 & 1.207 \\
\hline $\begin{array}{l}\text { Inspiration \& } \\
\text { Values }\end{array}$ & $\begin{array}{l}\text { I am satisfied to the way my boss } \\
\text { handles his/her sub ordinates. }\end{array}$ & 2.98 & 0.102 & 1.451 \\
\hline & $\begin{array}{l}\text { My immediate supervisor often asks my } \\
\text { opinion or suggestion. }\end{array}$ & 3.23 & 0.096 & 1.356 \\
\hline & $\begin{array}{l}\text { I have always given chance to be } \\
\text { "somebody" in the team/organization. }\end{array}$ & 3.3 & 0.095 & 1.346 \\
\hline & $\begin{array}{l}\text { I enjoy discussing about my } \\
\text { organization with people outside. }\end{array}$ & 3.18 & 0.105 & 1.484 \\
\hline Organization & I am satisfied with the way my & 3.35 & 0.088 & 1.249 \\
\hline
\end{tabular}




\begin{tabular}{|l|l|r|r|r|}
\hline Environment & co-workers get along with each other. & & & 1.188 \\
\cline { 2 - 5 } & $\begin{array}{l}\text { I am satisfied with the physical working } \\
\text { conditions. }\end{array}$ & 3.36 & 0.084 & 1.293 \\
\hline $\begin{array}{l}\text { Future Growth } \\
\text { \& Opportunity }\end{array}$ & $\begin{array}{l}\text { The organization place appropriate } \\
\text { methods to raise the level of learning } \\
\text { for employees. }\end{array}$ & $\begin{array}{l}\text { Employees are promoted when they } \\
\text { give contextual performance (perform } \\
\text { more than expected). }\end{array}$ & 0.091 & 1.307 \\
\hline
\end{tabular}

Items related to job hopping have mean scores in range 1.59 to 3.51 while the same items deviate in range 0.743 to 1.82 . The overall mean values suggest responses are more closely towards " $60 \%$ Agreement" at five-point Likert Scale. Items related to independent variable i.e. tangible rewards have mean scores in range 2.69 to 3.2 while the same items deviate in range 1.224 to 1.437 . The overall mean values posit responses are more closely towards " $60 \%$ Agreement" at five-point Likert Scale. Items related to other independent variables intangible rewards have mean scores in range 2.62 to 3.56 while the same items deviate in range 1.118 to 1.484. The overall mean values are above than average it suggests responses are more closely towards " $80 \%$ Agreement" at five-point Likert Scale.

\subsection{Inferential Statistics}

\subsubsection{Measurement of Outer Model}

The objective of proportion of fit in the estimation model is to learn about the reliability and validity of the instrument and to check its reliability and legitimacy we run trial of convergent validity and discriminant validity in Smart PLS software.

\subsubsection{Composite Reliability}

Reliability means consistency of survey results. This will give a response or comparative outcome at that point when the interviewer reuses the poll for a similar population. It demonstrates high internal consistency and repeatability of the survey. The primary basis for reliability is to keep away from unfairness in research. In this way, it tends to be improved by testing the inquiry procedure and examination, as is finished utilizing distinctive research and investigation strategies or different specialists. This additionally incorporates the dependability and legitimacy of the research. Reliability of the estimation instruments was assessed utilizing composite reliability. Each value was above the normal utilized edge value for example 0.70. This is the acknowledged reliability extend. Estimation of reliability should be possible by level of steadiness that lies among different factors (Siddiqui 2019). The following is the table of composite reliability.

Table 3.

\begin{tabular}{|l|r|}
\hline Variables & Cronbach's Alpha \\
\hline Job Hopping & 0.769 \\
\hline Tangible Rewards & 0.917 \\
\hline Intangible Rewards & 0.941 \\
\hline
\end{tabular}




\section{Macrothink Institute ${ }^{\text {TM }}$}

International Journal of Human Resource Studies

ISSN 2162-3058

2019, Vol. 9, No. 4

The idyllic value of Cronbach's Alpha is 0.7 to 1 . A questionnaire/survey is said to be consistent and solid if Cronbach's Alpha falls between stated ranges (Ekwoaba, Ikeije et al. 2015). The total numbers of items for job hopping are 13 and the Cronbach's Alpha value is 0.769. This is showing a solid and reliable Cronbach Alpha's. The Cronbach's Alpha for first independent variable tangible rewards has a value 0.917 with 3 sub variables of items 3 each. This is also a reliable coefficient. The Cronbach's Alpha for the second independent variable intangible rewards is 0.941 with 5 sub variables of items $3-5$ each. This coefficient is also reliable if compared to the range (0.7-1.00). Henceforth, all three variables are consistent and reliable.

4.2.3 Confirmatory Factor Analysis

Table 4. Confirmatory Factor Analysis

\begin{tabular}{|c|c|c|c|c|}
\hline Variables & Factor Loading & Job Hopping & Tangible Rewards & Intangible Rewards \\
\hline \multirow[t]{8}{*}{ Job Hopping } & CV1 & 0.7673 & & \\
\hline & $\mathrm{CV} 2$ & 0.7209 & & \\
\hline & CV3 & 0.7468 & & \\
\hline & LFAIJ & 0.5418 & & \\
\hline & NSBCWJOBHOP & 0.6623 & & \\
\hline & PTAYJH1 & 0.5990 & & \\
\hline & PTAYJH3 & 0.5777 & & \\
\hline & PTAYJH5 & 0.5257 & & \\
\hline \multirow[t]{9}{*}{ Tangible Rewards } & TRMB1 & & 0.7182 & \\
\hline & TRMB2 & & 0.7886 & \\
\hline & TRMB3 & & 0.7096 & \\
\hline & TRMCP1 & & 0.7943 & \\
\hline & TRMCP2 & & 0.7640 & \\
\hline & TRMCP3 & & 0.7738 & \\
\hline & TRPI1 & & 0.8093 & \\
\hline & TRPI2 & & 0.7969 & \\
\hline & TRPI3 & & 0.8091 & \\
\hline \multirow[t]{13}{*}{ Intangible Rewards } & IRFGandO1 & & & 0.7419 \\
\hline & IRFGandO2 & & & 0.6913 \\
\hline & IRIandV1 & & & 0.8088 \\
\hline & IRIandV2 & & & 0.7710 \\
\hline & IRIandV3 & & & 0.7815 \\
\hline & IRIandV4 & & & 0.7675 \\
\hline & IROE1 & & & 0.7229 \\
\hline & IROE2 & & & 0.6679 \\
\hline & IRQOW1 & & & 0.8203 \\
\hline & IRQOW2 & & & 0.7387 \\
\hline & IRQOW3 & & & 0.7810 \\
\hline & IRQOW4 & & & 0.7597 \\
\hline & IRQOW5 & & & 0.8280 \\
\hline
\end{tabular}




\begin{tabular}{|l|l|l|l|l|}
\hline & IRWLB1 & & & 0.4057 \\
\hline & IRWLB2 & & & 0.6441 \\
\hline & IRWLB3 & & & 0.7001 \\
\hline
\end{tabular}

It has been shown that nine factors related to independent variable tangible rewards has loading values above than 0.50. Furthermore, it is shown that fifteen factors related to independent variable intangible rewards has loading values above than 0.50 . While one item IRWLB1is eliminated due to irrespective loading. Lastly, it is shown that eight factors related to dependent variable job hopping has loading values above than 0.50 however 4 items are eliminated due to irrespective loading i.e. CHANGING JOB FREQUENTLY, NLTWFTOMT 1 TO 2 YEARS, QUIT JOB IN CAREER, QUIT JOB WITHIN 1YEAR and TTCONMT1YEAR.

\subsubsection{Construct Reliability \& Validity}

Table 5. Construct Reliability \& Validity

\begin{tabular}{|l|r|r|r|r|}
\hline \multicolumn{1}{|c|}{ Matrix } & \multicolumn{1}{|c|}{$\begin{array}{c}\text { Cronbach's } \\
\text { Alpha }\end{array}$} & rho_A & $\begin{array}{l}\text { Composite } \\
\text { Reliability }\end{array}$ & $\begin{array}{r}\text { Average Variance } \\
\text { Extracted (AVE) }\end{array}$ \\
\hline Job Hopping & 0.769 & 0.845 & 0.808 & 0.292 \\
\hline Tangible Rewards & 0.917 & 0.925 & 0.931 & 0.6 \\
\hline Intangible Rewards & 0.941 & 0.946 & 0.948 & 0.538 \\
\hline
\end{tabular}

Above table clearly shows that extracted value of variances are greater than 0.5 for all the variables including job hopping, tangible rewards and intangible rewards. And Cronbach's Alpha values are above than 0.70 . However, it supports convergent validity of instrument.

\subsubsection{Discriminant Validity}

Discriminant Validity can be characterized as any single figure when contrasts from other figures in the model (Carmines and Zeller 1979). Satisfactory are outcomes when the constructs having more than 0.5 AVE loading which means that minimum $50 \%$ of variance was acquired by the construct (Chin 1998).

Table 6. Discriminant Validity

\begin{tabular}{|l|r|r|r|}
\hline Variables & Intangible Rewards & Job Hopping & Tangible Rewards \\
\hline Intangible Rewards & 0.733 & & \\
\hline Job Hopping & 0.699 & 0.54 & \\
\hline Tangible Rewards & 0.71 & 0.508 & 0.775 \\
\hline
\end{tabular}

Present study explains that discriminate validity results show loading values are above than 0.5 so the results are satisfactory.

\subsubsection{PLS Algorithm}

Drawn table shows that $\mathrm{R}$ square value is 0.023 that suggests the variation triggered in job hopping behaviour of Generation $\mathrm{Y}$ is due to tangible rewards. This clearly reveals that tangible rewards have only $2.3 \%$ impact on job hopping behaviour. Furthermore, it is shown 


\section{Macrothink}

International Journal of Human Resource Studies

ISSN 2162-3058

2019, Vol. 9, No. 4

that $\mathrm{R}$ square value is 0.683 that suggests the variation triggered in job hopping behaviour due to intangible rewards. This clearly validates that intangible rewards have more impact i.e. $68.3 \%$ or

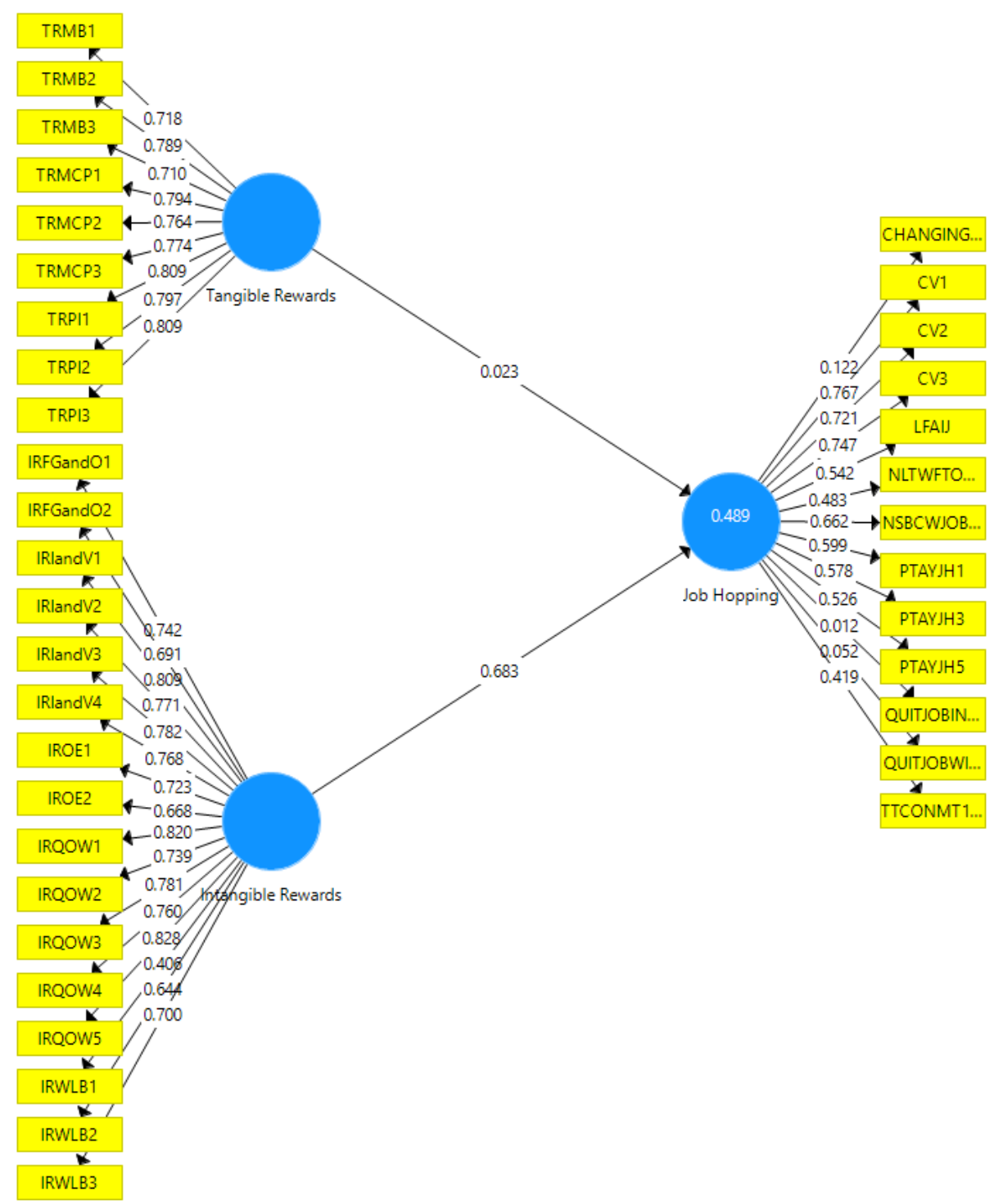

\subsubsection{Hypothesis Testing}

Table 7.

\begin{tabular}{|c|c|c|c|c|c|}
\hline Hypothesis & $\begin{array}{c}\text { Path } \\
\text { Coefficient }\end{array}$ & $\begin{array}{c}\text { Standard } \\
\text { Deviation } \\
\text { (STDEV) }\end{array}$ & T Values & P Values & Conclusion \\
\hline $\begin{array}{c}\text { Job hopping in Generation } \\
\text { 'Y' Employees is positively } \\
\text { associated with Tangible } \\
\text { Rewards. }\end{array}$ & 0.037 & 0.087 & 0.261 & 0.795 & Not Supported \\
\hline $\begin{array}{c}\text { Job hopping in Generation } \\
\text { 'Y' Employees is positively } \\
\text { associated with Intangible } \\
\text { Rewards. }\end{array}$ & 0.684 & 0.079 & 8.686 & 0.000 & Supported \\
\hline
\end{tabular}

Path coefficient is 0.037 , which means that the independent variable tangible rewards 


\section{Macrothink}

International Journal of Human Resource Studies

ISSN 2162-3058 2019, Vol. 9, No. 4

explains the $3.7 \%$ variation in the dependent variable job-hopping behavior of Generation $\mathrm{Y}$ in Karachi, Pakistan. The variation caused in dependent variable job hopping is insignificant owing to the $t$-value $0.261<1.96$ and $p$ value $0.795>0.05$. Path coefficient is 0.684 , which means that the independent variable intangible rewards explains the $68.4 \%$ variation in the dependent variable job-hopping behaviour of Generation $\mathrm{Y}$ in Karachi, Pakistan. The variation caused in dependent variable job hopping is significant owing to the t-value $8.686>$ 1.96 and $\mathrm{p}$ value $0.000<0.05$. Hence, we can accept that job-hopping in Generation ' $\mathrm{Y}$ ' employees is positively associated with Intangible Rewards.

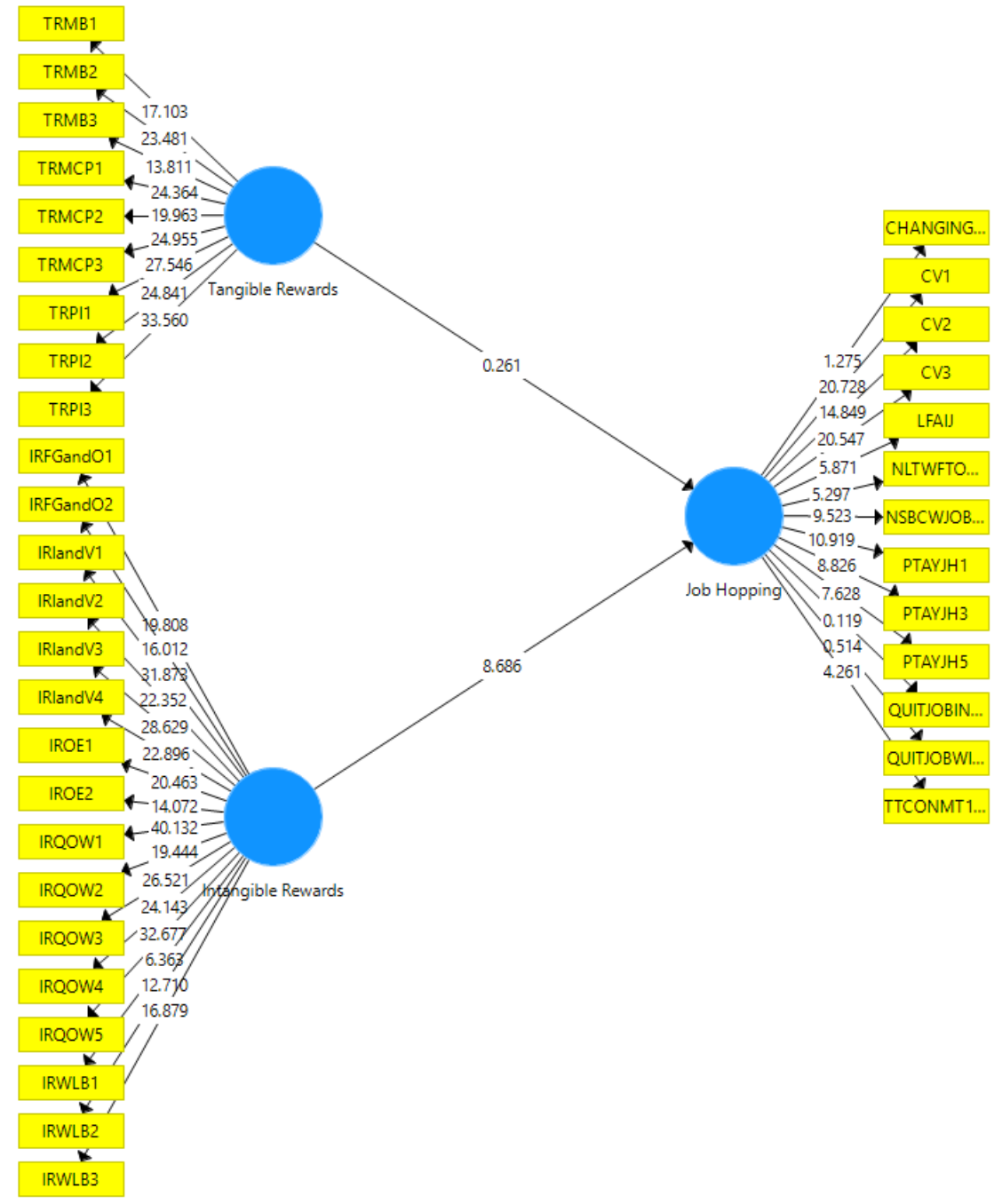

\subsubsection{PLS Bootstrapping}

In above table, we can understand the t-values and their significance. If t-value is $>1.96$ and the level of significance is $<0.05$ then alternate hypothesis is accepted and indicating the acknowledgement of the study. However, if the t-value $<1.96$ and level of significance is $>$ 0.05 , then alternate hypothesis is rejected and null hypothesis is accepted. In present study, we can see that tangible rewards and job hopping have the t-values $<1.96$ with level of significance 0.05 . So, alternate hypothesis is not accepted i.e. job hopping in Generation ' $Y$ ' employees is positively associated with tangible rewards. The t-value of intangible rewards is > 1.96 and level of significance is 0.05 which clearly showed job hopping in Generation 
' $\mathrm{Y}$ ' employees is positively associated with intangible rewards.

\subsection{Model Fit Measures}

The fitness of the model in SEM-PLS is defined by various measures such as standardized root-mean-square residual (SRMR), \& the exact model fits like d_ULS and d_G, Normed Fit Index (NFI), \& $\chi^{2}$ (Chi-square). The model fit measures consisting the measured value of both saturated model as well as the estimated model is reported in above Table. The saturated model assesses the correlation between all constructs. The estimated model, on the other hand, takes model structure into account $\&$ is based on total effect scheme.

Table 8.

\begin{tabular}{|l|c|c|}
\hline \multicolumn{2}{|c|}{ Fit Summary } \\
\hline SRMR & Saturated Model & Estimated Model \\
\hline d_ULS & 0.092 & 0.092 \\
\hline d_G & 6.232 & 6.232 \\
\hline Chi-Square & 2.317 & 2.317 \\
\hline NFI & $2,157.02$ & $2,157.02$ \\
\hline
\end{tabular}

\section{Discussion \& Analysis}

Researcher wanted to explore which play most significant role in increasing Job-Hopping Behavior in Generation Y Employees in Karachi, Pakistan? - Tangible Rewards or Intangible Rewards. For this research paper, data was collected from 201 employees who are working somewhere in any public and private organization in Karachi, Pakistan. Two hypotheses were tested. The first hypothesis of the study was "Job hopping in Generation ' $Y$ ' Employees is positively associated with Tangible Rewards". Being steady with past researches (Filipczak 1994, Jennings 2000, Bova and Kroth 2001) few employees accepted that they would get more significant compensations and become more skilled after job hopping, accordingly, their incentive in the organizations (i.e. marketability) would then be upgraded. The results of the research advocate that tangible rewards did not significantly effect on the job hopping behavior of Generation Y employees. The outcome are shown in Table 7. Thus, we did not discover support for the hypothesis one. The finding is comprehensively conflicting with the past literature which archives a positive effect of tangible rewards on job hopping behavior of Generation Y employees.

The second hypothesis of this research was "Job hopping in Generation ' $\mathrm{Y}$ ' Employees is positively associated with Intangible Rewards". Previous studies have discovered that Generation $\mathrm{Y}$ employees incline toward an open and relaxed social environment. It is additionally significant for this generation to be acknowledged by their bosses and colleagues. Millennial additionally offer significance to the greetings by team members (Kaye, Jordan-Evans et al. 2002). They are permitted to tackle issues autonomously with less obstruction from bosses and same rank peers (Zeiss 2010). Generation Y incline toward occupations that offer not only professional but personal growth also. Therefore, they are very much concerned about growth opportunities and development prospects inside the 
organization (Martin, Tulgan et al. 2001). The outcome are shown in Table 7. Thus, we discover support for the hypothesis two. The results showed that there is a optimistic relationship between intangible rewards \& job hopping. The finding is also reliable with the past literature.

Organizational environment or culture is the other factor that play a significant role for workers to leave organization. Many employees are affected by organizational environment as they are not satisfied or find themselves unfit in ongoing organizational environment or culture.

Work life balance also play a vital role for job hopping behavior. Encouraging employees for having life outside the boundaries of the organization. Organization can start by executing flexible hours for giving them more time so they also can focus on their personal life. Organizational politics states a variety of tasks related to the use of influential strategies to improve individual or organizational interests (Özen 2018). But the reality is organizational politics exists almost in every organization with negative aspects. But it is the leaders or managers responsibility to use it for the betterment of both employer and employee which can minimize turnover intentions of job hoppers.

Promotion / career growth / career advancement is also the major factor why millennial switch job if not given timely. Organization must disclose career path to employees at the time of onboarding so turnover ratio can be minimized. As rightly said humans are the social animal, as they spend additional time with colleagues in office than with family at house. Colleagues become their second family which can give impact on employees to stay in organization.

As CV is the first impression of job applicants from/by looking at the information on provided resumes or CVs employer decide to give applicant chance for job interview or not (Giacalone and Rosenfeld 2013).Readers of this study should get quite well about how human resources specialist or employers remark job applicants with job hopping track record.

\section{Conclusion}

No doubt, every individual has different needs and every employee have different view on rewards systems and job hopping. It can be stated that not all employees want just tangible rewards in order to stay longer in an organization. While for other employees, intangible reward matters most because at the end of the day we all are human being and human being have to align their personal and professional life to live peaceful life.

Findings of this research shows that an average \# of years a worker stay in one organization is 3 years. The important factors which compel an employee to hop job are; better salary package / market competitive pay, future growth and opportunity, work life balance/environment, lack of motivation, boss/manager bad behavior i.e. inspiration and value. $67.6 \%$ respondents belong to middle and senior management who have spent an average of 3 years plus in same organization. Around $38.8 \%$ switch job in professional career. $57.2 \%$ respondents have views that frequent job hopping imposes negative impact on resume/Cv. From employer/HR perspective, hiring candidates with job hopping trend in past 
will be depends upon the situation as hiring managers consider the cost of replacement as major hurdle of job hopping.

"According to a research which has been done in 2009, employees do not continue with the same company more than an average of 3.3 years" (Leidner and Smith 2013). It is clearly proved that the foremost factor which compel an employee to leave organization is "The Better Salary Package" which means employees are more concern about the tangible rewards, but once this requirement is fulfilled employees start thinking about intangible reward.

(Rivera) declared that employees including 59\% of millennial accepts that better opportunities for learning and growing are very important factor which play an important role for job hopping behavior. The most revealed factor that compel an employee to leave organization is "No Opportunity for Learning" and lack of motivation, motivation can differ from person to person. For some employees' tangible rewards is motivation or intangible rewards. Then the most rated factor is Boss/Manager bad behavior. Employees do not leave bad jobs, they leave bad bosses! A good boss makes your professional experience much better. No doubt employees spend more time at office then home they want to work in an environment where they feel appreciated and recognized by a boss. Intangible rewards matter, organization cannot retain employees if they have bad bosses. A good boss is no doubt a blessing to have.

\section{Recommendations \& Future Research}

By the help of this research researcher has identified the following practices that can help organizations in minimizing constant job switch by the employees:

- Appreciation and motivation by the employer.

- Learning, development and career counselling by the employer.

- Employer should offer market competitive salary package.

- Environment of organization should be professional.

- Employers must communicate employee's contribution in the company's vision and goals and make them realize what value they are adding in the industry.

- An organization should understand the rights of the employees and provide them such opportunities in order for them to work effectively and efficiently.

- Timely promotion, pleasant behavior of management, diversity in learning and work life balance may also help in minimizing job switching behavior.

- Good relationship and understanding with immediate boss may also help employees to work on their current job regardless of the work pressure.

- For employees if the motive is only earning that is obviously a time taking process which increases with experience. It is better for employees to keep their focus on Learning and then remove "L", earning will automatically start.

- Researcher also suggest the future researchers to explore some other variables which play an important role in job hopping behavior of different generations along with tangible and intangible rewards. The effect of gender, education, age can also be 
studied as a mediator while studying the effect of tangible and intangible rewards on job hopping behavior.

\section{Limitations}

Due to time constraint the sample size of this study is comparatively small i.e. 201 employees. In the composition of sample of 201 individuals approximately $14 \%$ are experienced professional holding senior management position is reputable organizations who have also shared their views over the topic. Moreover, due to scarcity of resources like time, budget etc. this research was conducted using Google forms.

\section{Acknowledgement}

Presentation, inspiration \& motivation have always played a key role in the success of any venture.

I would like to extend my heartiest thanks with a deep sense of gratitude \& respect to my research supervisor, Dr. Danish Ahmed Siddiqui for encouraging me to the highest peak \& providing me the opportunity to build up an understanding of the methodology of conducting research.

I would also like to thank my parents, their support, prayers \& ongoing encouragement is a motivation for me. I am also extremely grateful to my seniors and friends who gave valuable suggestions and guidance for completion of this research article. The cooperation and healthy criticism came handy and useful with them.

In conclusion, I offer my respects and endowments to those who upheld me in any regard amid the fulfillment of my research work.

\section{References}

Adams, J. (1963). S," Toward an understanding of inequality Journal of Abnormal and Social Psychology. TW $i T J i{ }^{\wedge} \wedge^{\prime} 2$ 2-W.

Aguinis, H., \& Glavas, A. (2012). What we know and don't know about corporate social responsibility: A review and research agenda. Journal of management, 38(4), 932-968. https://doi.org/10.1177/0149206311436079

Aguinis, H., \& Kraiger, K. (2009). Benefits of training and development for individuals and teams, organizations, and society. Annual review of psychology, 60, 451-474. https://doi.org/10.1146/annurev.psych.60.110707.163505

Ajila, C., \& Abiola, A. (2004). Influence of rewards on workers performance in an $\begin{array}{lllll}\text { organization. Journal of Social } & \text { Sciences, } & 8(1), & \text { 7-12. }\end{array}$ https://doi.org/10.1080/09718923.2004.11892397

Al-Nsour, M. (2012). Relationship between incentives and organizational performance for employees in the Jordanian Universities. International Journal of Business and Management, 7(1), 78. https://doi.org/10.5539/ijbm.v7n1p78 
Angeline, T. (2011). Managing generational diversity at the workplace: expectations and perceptions of different generations of employees. African Journal of Business Management, $5(2), 249-255$.

Armour, S. (2005). Generation Y: They've arrived at work with a new attitude. USA today, 6, 2005.

Armstrong, M. (2011). Armstrong's handbook of strategic human resource management. Kogan Page Publishers.

Armstrong, M., \& Murlis, H. (2007). Reward management: A handbook of remuneration strategy and practice. Kogan Page Publishers.

Armstrong, M., \& Taylor, S. (2014). Armstrong's handbook of human resource management practice. Kogan Page Publishers.

Arnold, T. J., Landry, T. D., Scheer, L. K., \& Stan, S. (2009). The role of equity and work environment in the formation of salesperson distributive fairness judgments. Journal of Personal Selling \& Sales Management, 29(1), 61-80. https://doi.org/10.2753/PSS0885-3134290104

Arthur, J. B. (1994). Effects of human resource systems on manufacturing performance and turnover. Academy of Management journal, 37(3), 670-687. https://doi.org/10.5465/256705

Aswathappa, K. E. M. A. L. (2005). Human resource and personnel management. Tata McGraw-Hill Education.

Ben-Ari, E., \& Clammer, J. (2013). Japan in Singapore: cultural occurrences and cultural flows. Routledge.

Bencsik, A., Horváth-Csikós, G., \& Juhász, T. (2016). Y and Z Generations at Workplaces. Journal of Competitiveness, 8(3). https://doi.org/10.7441/joc.2016.03.06

Bills, D. B. (1990). EMPLOYERS'USE OF JOB HISTORY DATA FOR MAKING HIRING DECISIONS: A Fuller Specification of Job Assignment and Status Attainment. Sociological Quarterly, 31(1), 23-35. https://doi.org/10.1111/j.1533-8525.1990.tb00315.x

bin Abdul, A., \& Abdul Rahman, A. A. A. (1999) Incentives System and Their Role in Promoting the Standard of Work Performance, Master's Thesis, Naif Arab University for Security Sciences, Riyadh.

Bova, B., \& Kroth, M. (2001). Workplace learning and Generation X. Journal of Workplace Learning, 13(2), 57-65. https://doi.org/10.1108/13665620110383645

Brown, E. A., Thomas, N. J., \& Bosselman, R. H. (2015). Are they leaving or staying: A qualitative analysis of turnover issues for Generation Y hospitality employees with a hospitality education. International Journal of Hospitality Management, 46, 130-137. https://doi.org/10.1016/j.ijhm.2015.01.011

Bullard, S. (2003). Recruiting Strategies for the New Millennium: A Corporate Guide to Building and Improving Your Company's Recruiting Process. iUniverse.

Campbell, D. J., \& Campbell, K. M. (1997). Employee turnover in Singapore: Some interim findings. 
Carmines, E. G., \& Zeller, R. A. (1979). Reliability and validity assessment (Vol. 17). Sage publications. https://doi.org/10.4135/9781412985642

Chin, W. W. (1998). The partial least squares approach to structural equation modeling. Modern methods for business research, 295(2), 295-336.

Chng, M. K., Low, L., Nga, T. B., \& Tyabji, A. (1986). Effective Mechanisms for the Enhancement of Technology and Skills in Singapore. Institute of Southeast Asian Studies. https://doi.org/10.1355/9789814377157

Cloutier, O., Felusiak, L., Hill, C., \& Pemberton-Jones, E. J. (2015). The Importance of Developing Strategies for Employee Retention. Journal of Leadership, Accountability \& Ethics, 12(2).

Cumming, D. (2012). The oxford handbook of entrepreneurial finance. Oxford University Press. https://doi.org/10.1093/oxfordhb/9780195391244.001.0001

D'Amato, A., \& Herzfeldt, R. (2008). Learning orientation, organizational commitment and talent retention across generations: A study of European managers. Journal of Managerial Psychology, 23(8), 929-953. https://doi.org/10.1108/02683940810904402

Daming, Z., \& Xiaoyun, S. (2010). Research on" job hopping" by migrant workers from the countryside: a second study on turnover among migrant workers employed by businesses. Chinese Sociology \& Anthropology, 43(2), 51-69.

Daniel, T. A., \& Metcalf, G. S. (2005). The fundamentals of employee recognition. Society of Human Resource Management.

Dougherty, T. W., Dreher, G. F., \& Whitely, W. (1993). The MBA as careerist: An analysis of early-career job change. Journal of Management, 19(3), 535-548. https://doi.org/10.1177/014920639301900302

Dries, N., Pepermans, R., \& Carlier, O. (2008). Career success: Constructing a multidimensional model. Journal of Vocational Behavior, 73(2), 254-267. https://doi.org/10.1016/j.jvb.2008.05.005

Edwards, J. R., \& Rothbard, N. P. (2000). Mechanisms linking work and family: Clarifying the relationship between work and family constructs. Academy of management review, 25(1), 178-199. https://doi.org/10.5465/amr.2000.2791609

Ekwoaba, J. O., Ikeije, U. U., \& Ufoma, N. (2015). The Impact of Recruitment and Selection Criteria on Organizational Performance.

Ellis, L., \& Pennington, S. (2004). Should leaders have tusks or fangs?. Management Today, 20(9), 32-33.

Filipczak, B. (1994). It's Just a Job: Generation X at Work. Training, 31(4), 21-27.

Freedman, S. M. (1978). Some determinants of compensation decisions. Academy of Management Journal, 21(3), 397-409. https://doi.org/10.2307/255722

Friedell, K., Puskala, K., Smith, M., \& Villa, N. (2011). Hiring, promotion, and progress: Millennials' expectations in the workplace. St. Olaf College Working Paper. 
Vijaya Kumar, D. B. J. G. (2017). THEORIES OF WORK LIFE BALANCE -A CONCEPTUAL REVIEW. International Research Journal of Management and Commerce, 4(9), 184-192.

Giacalone, R. A., \& Rosenfeld, P. (2013). Impression management in the organization. Psychology Press. https://doi.org/10.4324/9780203763018

Goleman, D., Boyatzis, R., \& McKee, A. (2001). Primal leadership: The hidden driver of great performance. Harvard business review, 79(11), 42-53.

Gordon, R. S. (2006). The nextgen librarian's survival guide. Information Today, Inc..

Hamori, M. (2010). Job-hopping to the top and other career fallacies. Harvard business review, 88(7-8), 154-157.

Hartman, S. J., \& Yrle, A. C. (1996). Can the hobo phenomenon help explain voluntary turnover?. International Journal of Contemporary Hospitality Management, 8(4), 11-16. https://doi.org/10.1108/09596119610119930

Helyer, R., \& Lee, D. (2012). The twenty-first century multiple generation workforce: Overlaps and differences but also challenges and benefits. Education+ Training, 54(7), 565-578. https://doi.org/10.1108/00400911211265611

Hirschfeld, R. R. (2000). Does revising the intrinsic and extrinsic subscales of the Minnesota Satisfaction Questionnaire short form make a difference?. Educational and Psychological Measurement, 60(2), 255-270. https://doi.org/10.1177/00131640021970493

Hom, P. W., Mitchell, T. R., Lee, T. W., \& Griffeth, R. W. (2012). Reviewing employee turnover: focusing on proximal withdrawal states and an expanded criterion. Psychological bulletin, 138(5), 831. https://doi.org/10.1037/a0027983

James, L. R. (1991). Testing hypotheses in the context of the unmeasured variables problem. Human Resource Management Review, 1(4), 273-291. https://doi.org/10.1016/1053-4822(91)90003-U

Jennings, A. T. J. J. o. A. (2000). Hiring generation-X, 189(2), 55. https://doi.org/10.1016/S0301-0511(00)00066-1

Jones, G. R., \& George, J. M. (2014). Essentials of contemporary management. McGraw-Hill Education.

Jurgensen, C. E. (1978). Job preferences (What makes a job good or bad?). Journal of Applied psychology, 63(3), 267. https://doi.org/10.1037/0021-9010.63.3.267

Kafeel, N., \& Alvi, A. K. (2015). What Play Significant Role in Increasing Turnover Intention: Job Hopping or Perceived Organizational Politics?. Sci. Int.(Lahore), 27(5).

Kaye, B., \& Jordan-Evans, S. (2002). Retention tough in times. Training \& Development, 56(1), 32-32.

Khatri, N., Budhwar, P., \& Fern, C. T. (1999). Employee turnover: bad attitude or poor management. Singapore: Nanyang Technological University, 2(5), 19-99.

Kilber, J., Barclay, A., \& Ohmer, D. (2014). Seven tips for managing Generation Y. Journal of Management Policy and Practice, 15(4), 80. 
Kim, H., Knight, D. K., \& Crutsinger, C. (2009). Generation Y employees' retail work experience: The mediating effect of job characteristics. Journal of Business Research, 62(5), 548-556. https://doi.org/10.1016/j.jbusres.2008.06.014

Korpi, T., \& Mertens, A. (2003). Training systems and labor mobility: A comparison between Germany and Sweden. Scandinavian Journal of Economics, 105(4), 597-617. https://doi.org/10.1111/j.0347-0520.2003.00005.x

Kupperschmidt, B. R. (2000). Multigeneration employees: Strategies for effective management. The health care manager, 19(1), 65-76. https://doi.org/10.1097/00126450-200019010-00011

La Motta, T. (1995). Recognition: The quality way: quality Resources. New York.

Lake, C. J., Highhouse, S., \& Shrift, A. G. (2018). Validation of the job-hopping motives scale. Journal of Career Assessment, 26(3), 531-548. https://doi.org/10.1177/1069072717722765

Lambert, M. (2015). Generational differences in the workplace: the perspectives of three generations on career mobility (Doctoral dissertation, The George Washington University).

Lankard, B. A. (1995). Career Development in Generation X. Myths and Realities.

Lau, A., \& Pang, M. (1995). Undergraduates' career perceptions and first job needs in Hong Kong. International Journal of Career Management, 7(3), 14-24. https://doi.org/10.1108/09556219510086760

Leidner, S., \& Smith, S. M. (2013). Keeping potential job-hoppers' feet on the ground: Well trained workers stay loyal to their employer. Human resource management international digest, 21(1), 31-33. https://doi.org/10.1108/09670731311296492

Lim, C.-Y., \& Chew, R. (1998). Wages and wages policies: tripartism in Singapore, World Scientific.

Macky, K., Gardner, D., \& Forsyth, S. (2008). Generational differences at work: Introduction and overview. Journal of Managerial Psychology, 23(8), 857-861.https://doi.org/10.1108/02683940810904358

Macky, K., Gardner, D., Forsyth, S., \& Cennamo, L. (2008). Generational differences in work values, outcomes and person-organisation values fit. Journal of managerial psychology.

Martin, C., et al. (2001). Global citizens born in the late seventies and early eighties, Massachusetts: HRD Press.

Mitchell, T. R., Holtom, B. C., \& Lee, T. W. (2001). How to keep your best employees: Developing an effective retention policy. Academy of Management Perspectives, 15(4), 96-108. https://doi.org/10.5465/ame.2001.5897929

Morris, M. B. (1981). The Public School as Workplace: The Principal as a Key Element in Teacher Satisfaction. A Study of Schooling in the United States. Technical Report Series, No. 32.

Mtungwa, I. Q. (2009). The Black Spot: A Critical Look at Transformation in the Workplace. The Black Spot. 
Naim, M. F., \& Lenka, U. (2018). Development and retention of Generation Y employees: a conceptual framework. Employee relations, 40(2), 433-455. https://doi.org/10.1108/ER-09-2016-0172

Naresh, B., \& Rathnam, B. V. (2015). Job Hopping In Software Industry With Reference To Select Software Companies: A Study. International Journal of Recent Research Aspects, 2(1), $38-45$.

Netswera, F. G., \& Rankhumise, E. M. (2005). Employee retention factors for South African higher education institutions: A case study. SA Journal of Human Resource Management, 3(2), 36-40. https://doi.org/10.4102/sajhrm.v3i2.64

Nkomo, W., \& Thwala, W. D. (2009). Problems facing construction companies in retention of employees in South Africa: A case study of Gauteng Province.

Özen, F. (2018). On the Intermediary Effect of Organizational Policy: The Effect of Perceived Ethical Climate on Corruption Behavior of Teachers. Journal of Education and Training Studies, 6(8), 52-65. https://doi.org/10.11114/jets.v6i8.3238

Phillips, D. R., \& Roper, K. O. (2009). A framework for talent management in real estate. Journal of Corporate Real Estate, 11(1), 7-16. https://doi.org/10.1108/14630010910940525

Reader, I., \& Soederberg, M. (2013). Japanese influences and presences in Asia, Routledge. https://doi.org/10.4324/9781315027630

Rivera, J. C. Human Resource Trends and Perspectives: An International HEI Experience.

Robertson, I. T., et al. (2001). Personnel selection. 74(4), 441-472. https://doi.org/10.1348/096317901167479

Saif, S. K., et al. (2012). Predicting job-satisfaction among the academicians of Universities in KPK, Pakistan. Industrial Engineering Letters, 2(2), 34-45.

Siddiqui, D. A. (2019). Impact of Motivation on Employees Performance in Pakistan. https://doi.org/10.5296/bms.v10i1.14448

Siddiqui, D. A. (2019). Impact of Motivation on Employees Performance in Pakistan. Rida, N. and Siddiqui, DA (2019). Impact of Motivation on Employees Performance in Pakistan. Business Management and Strategy, 10(1), 1-22. https://doi.org/10.5296/bms.v10i1.14448

Silverman, M. (2004). Non-financial recognition. The Most Effective of Rewards. Brighton: Institute for Employment Studies.

Sims, R. R. (Ed.). (2007). Human resource management: Contemporary issues, challenges and opportunities. IAP.

Smith, K. T. (2010). Work-life balance perspectives of marketing professionals in generation Y. Services Marketing Quarterly, 31(4), 434-447. https://doi.org/10.1080/15332969.2010.510724

Taylor, G. S., \& Zimmerer, T. W. (1992). Voluntary turnover among middle-level managers: An analysis of perceived causes. Journal of Managerial Issues, 424-437.

Twenge, J. M. (2010). A review of the empirical evidence on generational differences in work attitudes. Journal of Business and Psychology, 25(2), 201-210. https://doi.org/10.1007/s10869-010-9165-6 


\section{Macrothink}

International Journal of Human Resource Studies

ISSN 2162-3058 2019, Vol. 9, No. 4

Vroom, V. H. (1964). Work and motivation. new york: John willey \& sons. Inc. VroomWork and Motivation1964.

Weyland, A. (2011). Engagement and talent management of Gen Y. Industrial and commercial training, 43(7), 439-445. https://doi.org/10.1108/00197851111171863

Williams, S., \& Turnbull, S. (2015). Developing the next generation of globally responsible leaders: Generation Y perspectives and the implications for green HRD. Advances in Developing Human Resources, 17(4), 504-521. https://doi.org/10.1177/1523422315599623

Witt, T. C. (2016). IT best practices: management, teams, quality, performance, and projects, Auerbach Publications. https://doi.org/10.1201/b11475

Yah, L. C. (2013). Singapore's National Wages Council: An Insider's View. World Scientific.

Yeaton, K. (2008). Recruiting and managing the'why?'generation: Gen Y. The CPA Journal, $78(4), 68$.

YUEN, S. H. (2016). Examining the generation effects on job-hopping intention by applying the Theory of Planned Behavior (TPB).

Zeiss, T. (2010). Get'em while they're hot: How to attract, develop, and retain peak performers in the coming labor shortage, HarperCollins Leadership.

\section{Copyright Disclaimer}

Copyright for this article is retained by the author(s), with first publication rights granted to the journal.

This is an open-access article distributed under the terms and conditions of the Creative Commons Attribution license (http://creativecommons.org/licenses/by/4.0/). 